Volume 2, Issue 1, pages 23-34

p-ISSN 2655-8564, e-ISSN 2685-9432

\title{
Characteristics of Solar Still with Heat Exchangers on the Cover Glass
}

\author{
Ignasius Dinang Yudra Nanda ${ }^{1, *}$, F. A. Rusdi Sambada ${ }^{1}$, \\ Yulianto $^{1}$, Angelina Boru Sitio ${ }^{2}$ \\ ${ }^{1}$ Department of Mechanical Engineering, Sanata Dharma University, \\ Yogyakarta, Indonesia \\ ${ }^{2}$ Department of Mathematics and Natural Sciences Education, Sanata \\ Dharma University, Yogyakarta, Indonesia \\ *Corresponding Author: dinangyudra@gmail.com
}

(Received 14-07-2019; Revised 19-01-2020; Accepted 19-01-2020)

\begin{abstract}
Drinking water is one of the main needs of human life. Water sources do not always have the feasibility to drink. Distillation is one way to obtain potable water. Distillation can influence on drinking water quality. Low performance is a major problem in distillation. One way to improve performance is by increasing the input water temperature. One way to increase the input water temperature by utilizing heat energy on the cover glass. This study aims to improve the performance of solar energy water distillation and input water temperature by a heat exchanger. This research method is experimental. The measured variables are absorber temperature in the distillation model $\left(T_{1}\right)$, glass temperature $\left(T_{2}\right)$, ambient temperature $\left(T_{a}\right)$, amount of distilled water produced $(m)$ and heat energy coming from solar energy $(G)$. This research uses variations, namely with a white or black heat exchanger and without heat exchanger. Water quality tested using 4 parameters such as microbiology, inorganic chemistry, physical and
\end{abstract}




\section{International Journal of Applied Sciences and Smart Technologies}

Volume 2, Issue 1, pages 23-34

p-ISSN 2655-8564, e-ISSN 2685-9432

chemical. Based on this study, the best results produced by a black heat exchanger using a water flow rate of $2 l / h$ which produce distillation water $422 \mathrm{ml}\left(480 \mathrm{ml} /\left(\mathrm{m}^{2} . \mathrm{h}\right)\right)$ and efficiency value of $79.74 \%$. While the best results using white heat exchanger is using $0.7 \mathrm{l} /$ hour water flow rate which produces distillation water of $\left.497 \mathrm{ml} /\left(\mathrm{m}^{2} . h\right)\right)$ and efficiency value of $82.63 \%$, Distilled water has increased in quality even though it has not met the standards No. 492 of 2010.

Keywords: distillation, solar energy, glass cover, water quality, efficiency.

\section{Introduction}

Water is one of the basic human needs that is used mainly for drinking water. Not all regions in Indonesia have water sources that are suitable for drinking, as is the case in Gunung Kidul district, Yogyakarta, which is experiencing difficulties with clean water [1]. The water sources that are often contaminated with soil, salt (seawater) or other materials. Water with these conditions can interfere with health if used directly.

Distillation is evaporation of dirty water (contaminated water) then the steam is condensed again. Steam from dirty water does not carry substances that pollute it so that the water produced from this steam condensation is feasible to drink [2].

The low performance of distillation is caused by the ineffectiveness of the evaporation and condensation process [4]. One way to increase the effectiveness of the evaporation process is to increase the temperature of the water entering the distillation. Increasing the temperature of the water entering the distillation makes the water more easily evaporated. A common way to increase the temperature of the input water is to use a solar energy water heater collector. This method requires a lot of investment costs for the manufacture of water heater collectors. In this study, another method that is cheaper and easier to use is to increase the temperature of the input water by utilizing the heat energy contained in the cover glass.

The utilization of heat energy in the cover glass is done by adding a simple heat exchanger. The heat exchanger integrated into the cover glass functions to take heat energy on the cover glass and give it to the input water. This causes the temperature of 


\section{International Journal of Applied Sciences and Smart Technologies}

Volume 2, Issue 1, pages 23-34

p-ISSN 2655-8564, e-ISSN 2685-9432

the input water to increase and the glass temperature to decrease. Increasing the temperature of the input water will increase the effectiveness of the evaporation process and the reduction in glass temperature will increase the effectiveness of condensation.

This study will analyze the utilization of heat energy in a cover glass to improve the performance of water distillation with solar energy. The purpose of this study is to increase the temperature of input water distillation with heat exchanger, increase the performance of the distillation of solar water by utilizing heat energy in cover glass, and to determine the quality analysis of the quality of distilled water as drinking water.

\section{Research Methods}

This research method is experimental. The distillation model used in indoor test includes 3 variations, white or black heat exchanger and without heat exchanger. While the variations used for outdoor include without heat exchanger and with a black heat exchanger. The input water flow rate used in indoor and outdoor research is $0.7 \mathrm{l} /$ $h, 1.3 l / h$, and $2 l / h$. Data collection for each variation is done every 3 sunny days. Data recording is done by using sensors that are regulated by the Arduino microcontroller. In Figure 1, we can see the scheme of the tools used in this study. The main parts of this solar still include input water reservoir, heat exchanger, cover glass, absorber, non-evaporating water tank, and clean water tank.

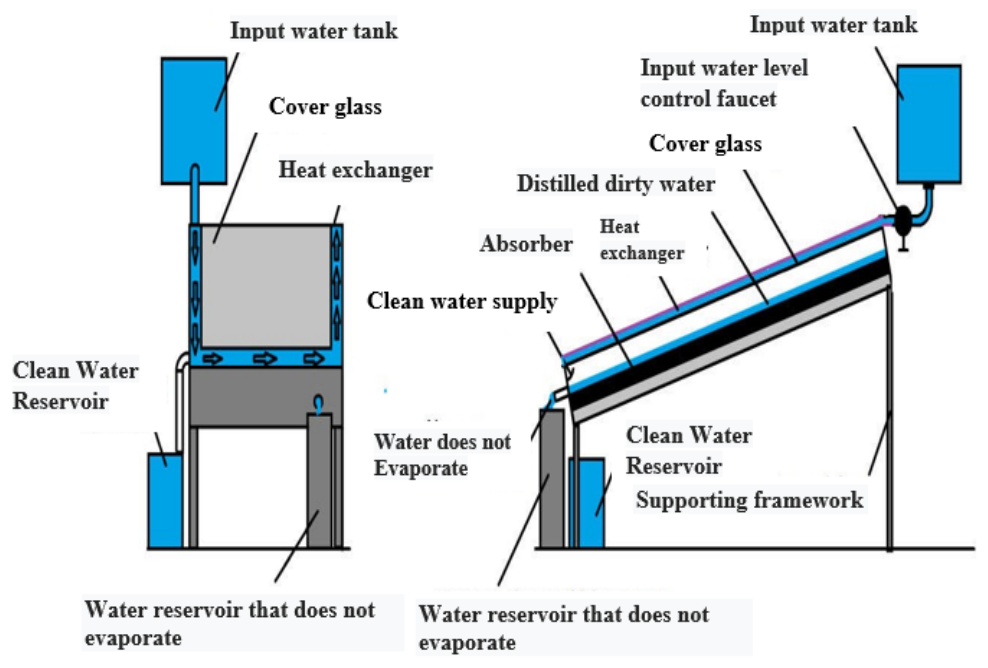

Figure 1. Parts of solar still 


\section{International Journal of Applied Sciences and Smart Technologies}

Volume 2, Issue 1, pages 23-34

p-ISSN 2655-8564, e-ISSN 2685-9432

For water analysis using 2 water sources, namely the source of river water and wells. Analysis of water quality carried out in the government laboratory i.e. BBTKLP is good for analysis before being distilled or after being distilled.

Data analysis used to see the performance of the distillation models used include solar energy:

$$
\eta=\frac{q_{e}}{I(t)}
$$

Where $q_{e}$ is solar energy for the evaporation process $\left(W / m^{2}\right)$ and $I(t)$ is the solar energy received by the distillation apparatus $\left(W / \mathrm{m}^{2}\right)$. The rate of evaporation is:

$$
m_{e}=q_{e} / h_{f g}
$$

Where me is the rate of evaporation of the mass of water $\left(\mathrm{kg} /\left(\mathrm{s} . \mathrm{m}^{2}\right)\right.$ and $h_{f g}$ is the latent heat of evaporation of water $(J / \mathrm{kg})$. Some heat energy is converted and radiated from glass to the environment. Constructed energy is calculated by:

$$
q=h\left(T_{1}-T_{2}\right)
$$

Where $\mathrm{q}$ is convection to the environment, $q_{c a}\left(W / \mathrm{m}^{2}\right), \mathrm{h}$ is the convection coefficient, hca $\left(W / m^{2} \cdot{ }^{\circ} \mathrm{C}\right)$, T1 is the temperature of the glass, $T_{g}\left({ }^{\circ} \mathrm{C}\right)$ and $T_{2}$ is the ambient air temperature $\left({ }^{\circ} C\right), T_{a}\left({ }^{\circ} C\right)$. Glass radiation energy into the environment is calculated using:

$$
q_{r a}=\frac{\sigma\left[\left(T_{1}+273,15\right)^{4}-\left(T_{2}+273,15\right)^{4}\right]}{\left(\frac{1}{\varepsilon_{1}}+\frac{1}{\varepsilon_{2}}-1\right)}
$$

Where $q_{r a}$ is radiation to the environment, $q_{r a}\left(W / m^{2}\right), \sigma$ is Stefan Boltzmann's constant $\left(5.67 \times 10-8 \mathrm{~W} /\left(\mathrm{m}^{2} \cdot \mathrm{K}^{4}\right)\right), T_{1}$ is the glass temperature, $T_{g}\left({ }^{\mathrm{o}} \mathrm{C}\right), \mathrm{T}_{2}$ is the sky temperature, $T_{s k y}\left({ }^{\circ} C\right), \varepsilon_{1}$ is the emissivity of water, $\varepsilon_{w}$ and $\varepsilon_{2}$ are celestial emissivity, $\varepsilon_{s k y}\left(\varepsilon_{s k y} \approx 1\right)$. The energy for evaporation is calculated by the equation:

$$
q_{e}=16,273 \times 10^{-3} \cdot h_{c} \cdot\left(P_{w}-P_{g}\right)
$$

Where $P_{w}$ and $P_{g}$ are partial vapor pressures at water and glass temperatures. The heat energy in the cover glass that can be utilized can be calculated by the equation:

$$
q_{k a c a}=m \cdot C_{p .}\left(T_{2}-T_{1}\right)
$$




\section{International Journal of Applied Sciences and Smart Technologies}

Volume 2, Issue 1, pages 23-34

p-ISSN 2655-8564, e-ISSN 2685-9432

Where $\mathrm{m}$ is the input water flow rate $(\mathrm{kg} / \mathrm{s}), \mathrm{Cp}$ is the water heat capacity $(\mathrm{J} /$ $\left.\left(\mathrm{kg} .{ }^{\mathrm{o}} \mathrm{C}\right)\right), T_{1}$ is the temperature of the input water entering the heat exchanger $\left({ }^{\circ} \mathrm{C}\right)$ and $T_{2}$ is the temperature of the water entering the exchanger $\left({ }^{\circ} C\right)$.

The results of the analysis of water data obtained are then evaluated by comparing the data obtained with drinking water quality requirements according to The Minister of Health Regulation No. 492 of 2010 [3]. If the data obtained meets the conditions specified by the minister of health regulations as described in the theoretical basis, distilled water qualify as drinking water and can be consumed directly.

\section{Results and Discussion}

The results of tools that work indoor can be seen in Figures 2, 3 and 4. In Figures 2, 3 and 4 that variations without heat exchanger are marked with brown, variations using a white heat exchanger are marked in white, and variations using a black heat exchanger are marked in black.

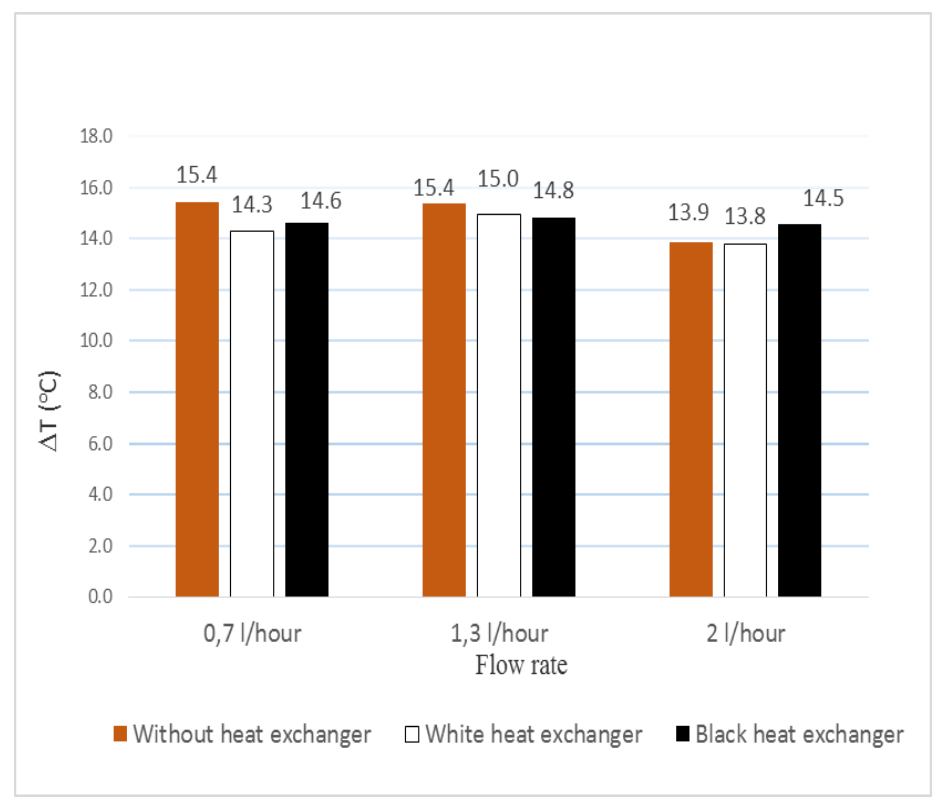

Figure 2. Graph of the average temperature difference between absorber and glass at indoor

Figure 2 is a graph of the average temperature difference $(\Delta T)$ between absorber and glass produced by various variations of water flow discharge and heat exchanger. The highest difference in temperature between the absorber and glass in the variation using 


\section{International Journal of Applied Sciences and Smart Technologies}

Volume 2, Issue 1, pages 23-34

p-ISSN 2655-8564, e-ISSN 2685-9432

black heat exchanger was obtained using $1.3 \mathrm{l} / \mathrm{h}$ flow rate which is $14.8^{\circ} \mathrm{C}$ then followed by flow rate $0.7 \mathrm{l} / \mathrm{h}$ i.e. $14.6{ }^{\circ} \mathrm{C}$, the lowest average temperature at $2 \mathrm{l} / \mathrm{h}$ flow rate which is $14.5^{\circ} \mathrm{C}$.

Figure 3 is a graph of the volume results generated by various variations of water flow rate and heat exchangers. The image shows the highest volume produced by the variation of the black heat exchanger using an input water flow rate of $2 l / h$ which is $422 \mathrm{ml}$, while the lowest volume uses input water flow rate of $1.3 \mathrm{l} /$ hour which is $397 \mathrm{ml}$.

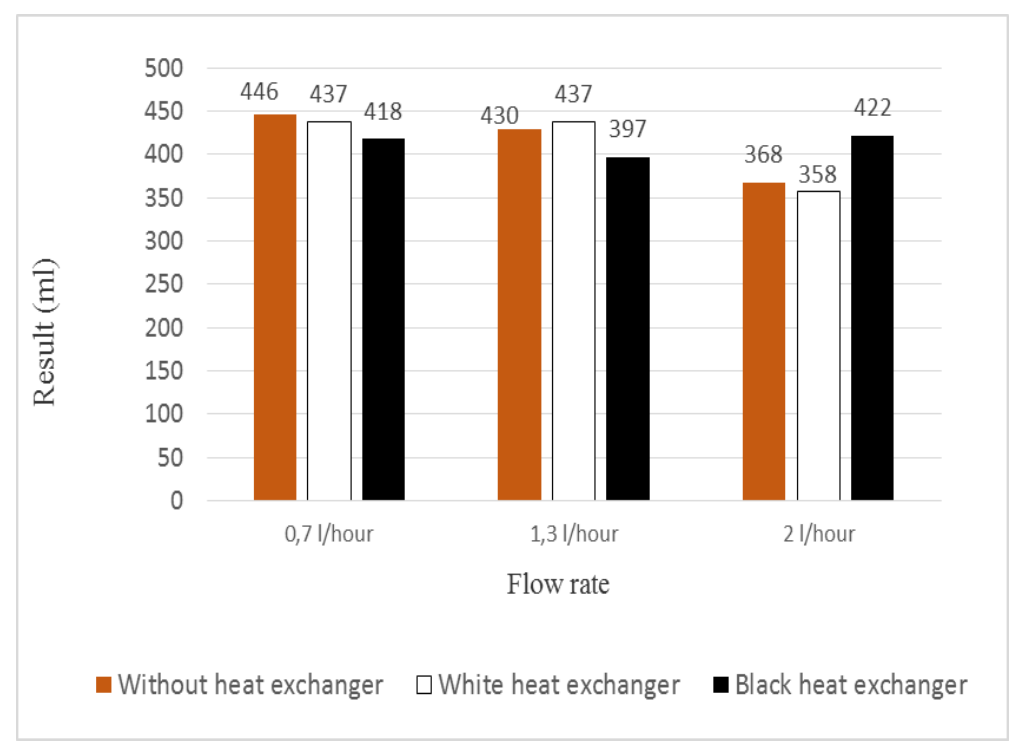

Figure 3. Graph of results of indoor distillation data

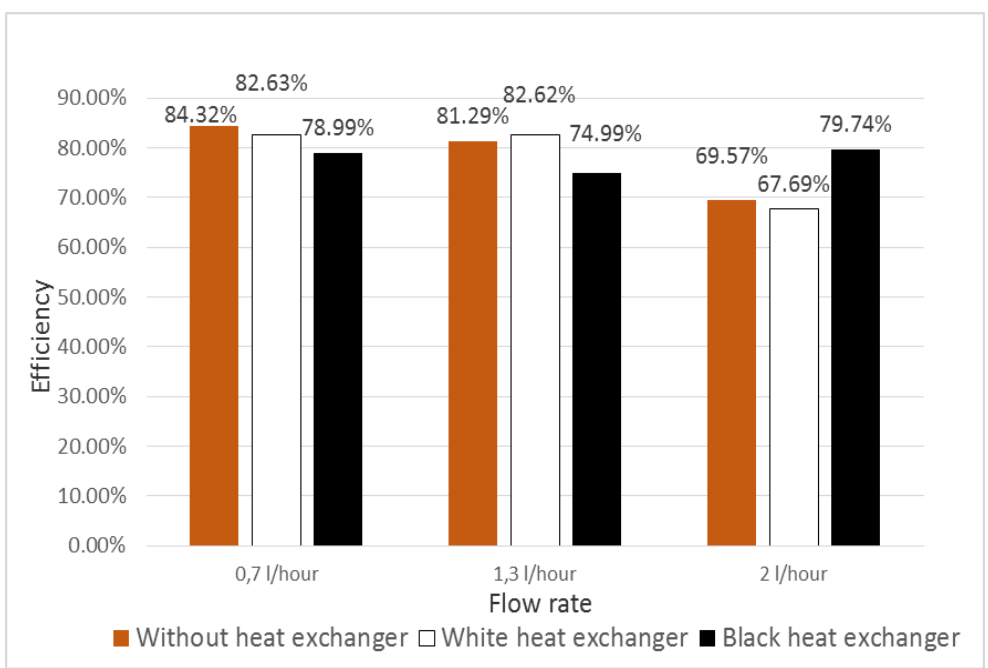

Figure 4. Indoor data collection efficiency graph 


\section{International Journal of Applied Sciences and Smart Technologies}

Volume 2, Issue 1, pages 23-34

p-ISSN 2655-8564, e-ISSN 2685-9432

Figure 4 is a graph of efficiency produced by several variations of input water flow rate and heat exchanger. The graph shows the variation using a black heat exchanger which produces the highest efficiency using $2 l / h$ water flow rate which is $79.74 \%$. While the lowest efficiency uses $1.3 l / h$ water flow rate which is $74.99 \%$.

The results of tools that work outdoors can be seen in Figures 5, 6, and 7. Outdoor data collection is carried out for 7 hours.

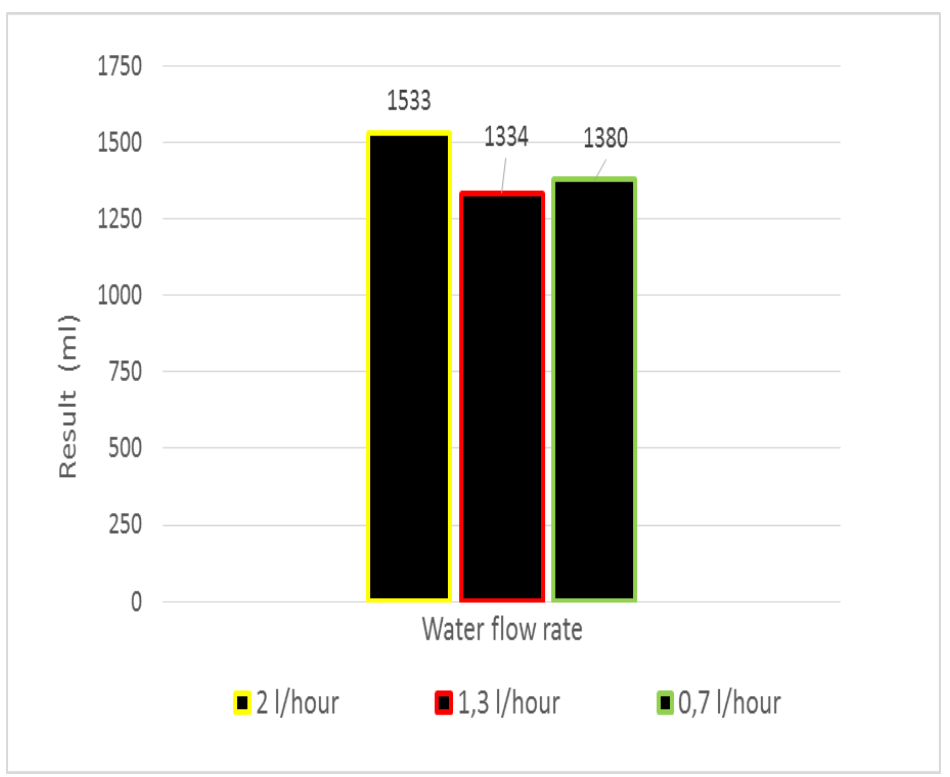

Figure 5. Graph of outdoor distillation using black heat exchanger

In Figure 5, it is known that the highest yield of black heat exchanger variations uses water flow rate $2 l / h$ which is $1533 \mathrm{ml}$, while the lowest results are obtained using a $1.3 \mathrm{l} / \mathrm{h}$ water flow rate which is $1334 \mathrm{ml}$. 


\section{International Journal of Applied Sciences and Smart Technologies}

Volume 2, Issue 1, pages 23-34

p-ISSN 2655-8564, e-ISSN 2685-9432

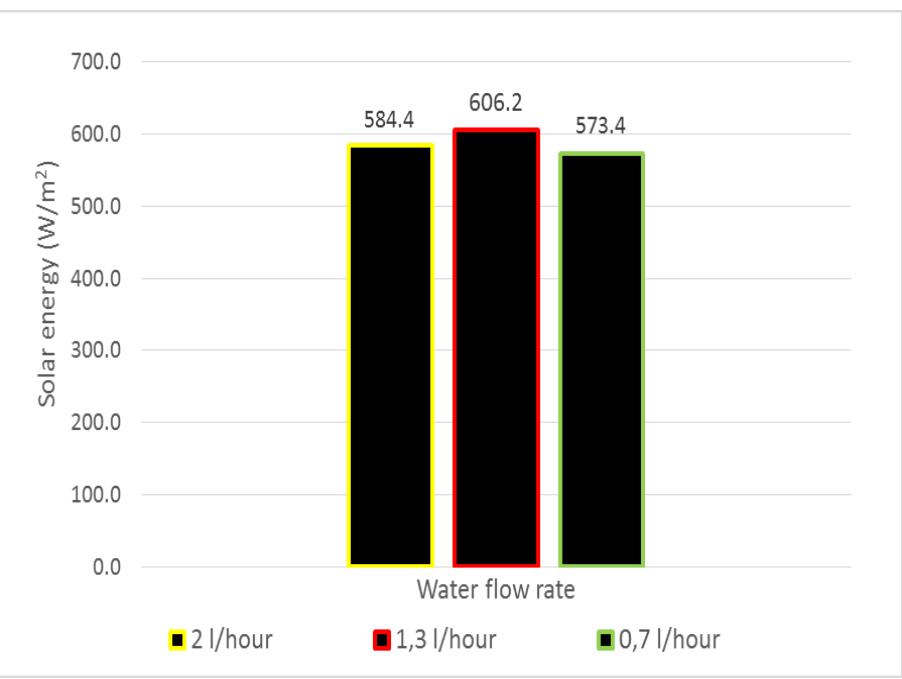

Figure 6. Average graph of the amount solar energy when taking outdoor data

Figure 6 is the average solar energy that occurs during data collection. The biggest energy occurs when the data collection uses a $1.3 l / h$ water flow rate reaching $606.2 \mathrm{~W} / \mathrm{m}^{2}$ and the smallest at $0.7 \mathrm{l} / \mathrm{h}$ water flow rate is $573.4 \mathrm{~W} / \mathrm{m}^{2}$.

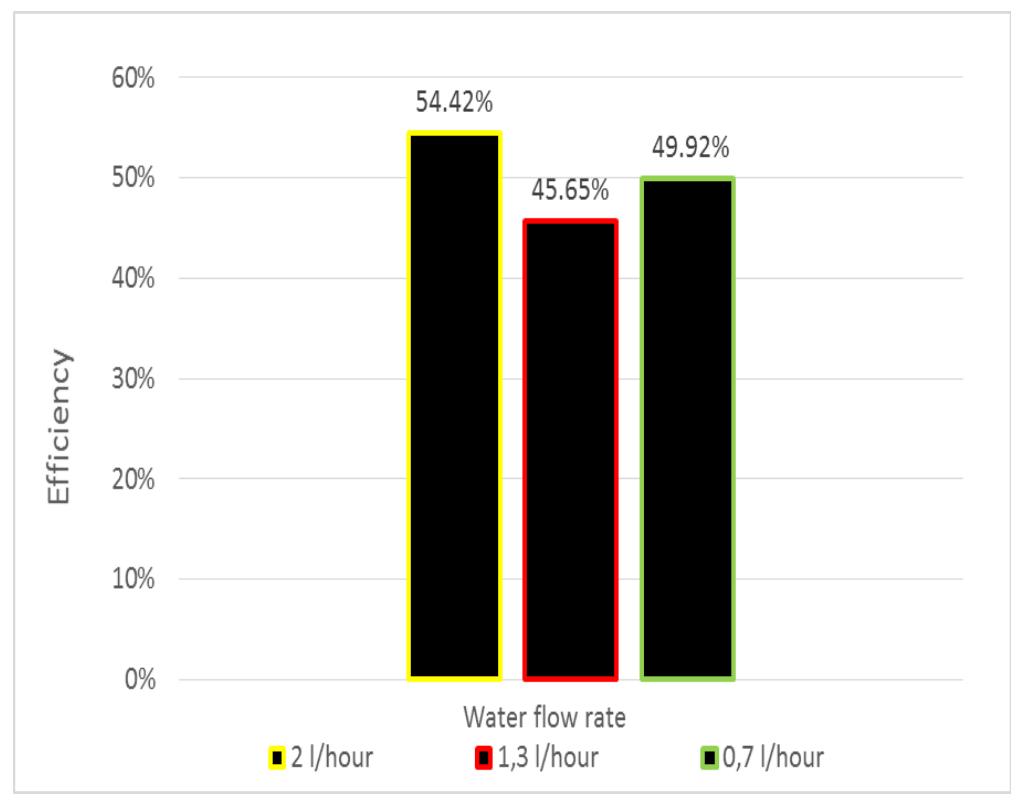

Figure 7. Graph of efficiency of the distillation tool when outdoor

Figure 7 is the efficiency produced during data collection. It can be seen that the highest efficiency is obtained at $2 l / h$ water flow rate, which is $54.42 \%$ and the lowest is $1.3 l / h$ water flow rate which is $45.65 \%$. 


\section{International Journal of Applied Sciences and Smart Technologies}

Volume 2, Issue 1, pages 23-34

p-ISSN 2655-8564, e-ISSN 2685-9432

Table 1. Standard quality of water analysis

\begin{tabular}{|c|c|c|c|c|c|c|}
\hline \multirow[t]{2}{*}{ No } & \multirow[t]{2}{*}{ Parameter } & \multicolumn{2}{|c|}{ Wells Water } & \multicolumn{2}{|c|}{ River Water } & \multirow{2}{*}{$\begin{array}{c}\text { Maximum } \\
\text { Level }\end{array}$} \\
\hline & & Before & After & Before & After & \\
\hline 1 & Arsenic $(m l / L)$ & $<0,005$ & $<0,005$ & $<0,005$ & $<0,005$ & 0,01 \\
\hline 2 & Fluoride $(m l / L)$ & $<0,0308$ & $<0,0308$ & $<0,0308$ & $<0,0308$ & 1,5 \\
\hline 3 & $\begin{array}{l}\text { Total chromium } \\
(\mathrm{ml} / \mathrm{L})\end{array}$ & $<0,0213$ & $<0,0213$ & $<0,0213$ & $<0,0213$ & 0.005 \\
\hline 4 & Cadmium $(m l / L)$ & $<0,0004$ & $<0,0004$ & $<0,0004$ & $<0,0004$ & 0,003 \\
\hline 5 & Nitrite $(m l / L)$ & $<0,0013$ & 0,0015 & 0,0033 & $<0,0013$ & 3 \\
\hline 6 & Nitrate $(m l / L)$ & 10,85 & 1,24 & 8,54 & 1,24 & 50 \\
\hline 7 & Cyanide $(m l / L)$ & $<0,0070$ & $<0,0070$ & $<0,0070$ & $<0,0070$ & 0,07 \\
\hline 8 & Selenium $(m l / L)$ & 0,0067 & 0,0062 & 0,0010 & 0,0015 & 0,01 \\
\hline 9 & $\operatorname{Iron}(m l / L)$ & 0,1230 & 0,1037 & 0,1230 & 0,1134 & 0,03 \\
\hline 10 & Hardness $(m l / L)$ & 165,00 & 5,00 & 192,00 & 3,00 & 500 \\
\hline 11 & Chloride & 15,1 & $<0,6$ & 15,1 & $<0,6$ & 250 \\
\hline 12 & Manganese $(m l / L)$ & $<0,0101$ & $<0,0101$ & $<0,0101$ & $<0,0101$ & 0,4 \\
\hline 13 & $\mathrm{pH}$ & 6,8 & 7,1 & 6,5 & 7,1 & $6,5-8,5$ \\
\hline 14 & $\operatorname{Zinc}(m l / L)$ & $<0,0083$ & $<0,0165$ & $<0,0083$ & $<0,0233$ & 3 \\
\hline 15 & Sulphate $(m l / L)$ & 28 & 5 & 16 & 5 & 250 \\
\hline 16 & Copper $(m l / L)$ & $<0,0069$ & $<0,0069$ & $<0,0069$ & $<0,0069$ & 2 \\
\hline 17 & Ammonia $(m l / L)$ & $<0,0003$ & $<0,0003$ & $<0,0003$ & $<0,0003$ & 1,5 \\
\hline 18 & $\operatorname{Nickel}(m l / L)$ & $<0,0130$ & $<0,0130$ & $<0,0130$ & $<0,0130$ & 0,07 \\
\hline 19 & Sodium $(m l / L)$ & 14 & 2 & 15 & 2 & 200 \\
\hline 20 & Chlorine $(m l / L)$ & $<0,03$ & $<0,03$ & 0,05 & $<0,03$ & 5 \\
\hline 21 & Lead $(m l / L)$ & 0,0058 & 0,0017 & $<0,0008$ & 0,0011 & 0,01 \\
\hline 22 & $\begin{array}{l}\text { Organic matter } \\
(m l / L)\end{array}$ & 1,84 & 0,61 & 2,77 & 1,23 & 10 \\
\hline 23 & Detergent $(m l / L)$ & 0,1498 & 0,0002 & 0,0219 & 0,1588 & 0,05 \\
\hline 24 & Aroma & No & No & No & No & No \\
\hline 25 & Color (TCU) & 1 & $<1$ & 1 & $<1$ & 15 \\
\hline 26 & $\operatorname{TDS}(m l / L)$ & 293 & 23 & 310 & 10 & 500 \\
\hline 27 & Turbidity (MTU) & 0,4 & 0,3 & 1,8 & 0,4 & 5 \\
\hline 28 & Taste & No & No & No & No & No \\
\hline 29 & Temperature $\left({ }^{\circ} \mathrm{C}\right)$ & 26 & 37 & 27 & 37 & $\begin{array}{c}\text { water } \\
\text { temperature } \\
\pm 3\end{array}$ \\
\hline 30 & $\begin{array}{l}\text { E.coli } \\
(\mathrm{CCFU} / 100 \mathrm{ml})\end{array}$ & 0 & 0 & 0 & 0 & 0 \\
\hline 31 & Total coliform & 23 & 6 & TNTC & 3 & 0 \\
\hline
\end{tabular}




\section{International Journal of Applied Sciences and Smart Technologies}

Volume 2, Issue 1, pages 23-34

p-ISSN 2655-8564, e-ISSN 2685-9432

For the results of testing the water quality standards can be seen in Table 1, that wells and rivers that have been distilled have not met drinking water quality standards according to The Minister of Health Regulation No. 492 of 2010. The wells and rivers after being distilled have decreased and increased levels of physical and chemical and microbiological water. Decreased levels of physical, chemical and biological wells after distillation occur in the nitrate, selenium, iron, hardness, chloride, sulfate, sodium, lead, organic matter, detergent, color, TDS, coliform and turbidity. Whereas in river water there is a decrease in nitrite, nitrate, iron, hardness, chloride, sulfate, sodium, organic matter, chlorine, color, TDS, coliform, $\mathrm{pH}$, temperature, and turbidity. The increase in the chemical content of distilled well water occurs in the nitrite $\mathrm{pH}$, temperature and zinc content. While the distillation of river water has increased levels of zinc, selenium, lead, and detergent.

Basically water after being distilled decreases the physical and biological levels of chemicals contained in water. in this study, the increase in chemical content in water can occur due to human error or contamination by the equipment used. Even though there was an increase in the chemical content contained in well water and river water some of the contents still included drinking water quality standards except detergent in river water. Some of the contents have decreased levels of physical, chemical and biological decline, making some of the content into the drinking water quality standard.

\section{Conclusion}

From the results of this study, some conclusions can be obtained, including:

1. The highest water volume is obtained using a black heat exchanger at a flow rate of $2 l / h$ i.e $1533 \mathrm{ml}$.

2. The highest efficiency is obtained by using a black heat exchanger at a flow rate of $2 l / h$ i.e $54.42 \%$.

3. Wells and river water after being distilled have better quality even though they have not met the standards of quality of the Permenkes No. 492 of 2010. 


\section{International Journal of Applied Sciences and Smart Technologies}

Volume 2, Issue 1, pages 23-34

p-ISSN 2655-8564, e-ISSN 2685-9432

\section{Acknowledgements}

Thank you to the Ministry of Research, Technology, and Higher Education of the Republic of Indonesia for financing this research.

\section{References}

[1] Metrotvnews, Kabupaten Gunung Kidul Krisis Air Bersih. Jakarta: Metrotvnews. 2017.

[2] H. Effendi. Telaah Kualitas Air Bagi Pengelolaan sumber Daya dan Lingkungan Perairan. Yogyakarta: Kanisius. 2003.

[3] D. Purwodianto, FA. Rusdi Sambada,’Unjuk Kerja Destilasi Air Energi Surya Menggunakan Kondenser Pasif ,“Jurnal Penelitian, 17 (1), 34-41, 2013.

[4] http://www.airminum.or.id/permenkes-4922010-persyaratan-kualitas-airminum.html (Accessed on 22-10-2019). 
International Journal of Applied Sciences and Smart Technologies

Volume 2, Issue 1, pages 23-34

p-ISSN 2655-8564, e-ISSN 2685-9432

This page intentionally left blank 